\title{
Growth and Grain Yield of Hybrid Maize (Zea mays L) under Different Plant Geometry and Fertility Levels
}

\author{
Rajesh Babu*, Rampyare and Puspendra Kumar \\ Department of Agronomy, C. S. Azad University of Agriculture and Technology, \\ Kanpur-208 002 (Uttar Pradesh), India \\ *Corresponding author
}

\section{Keywords}

Growth, Grain yield, Plant geometry, Fertility

Article Info

Accepted:

07 October 2019

Available Online:

10 November 2019
A field investigation was carried out during two consecutive seasons of Kharif 2013-14 and 2014-15 at Students' Instructional Farm, Chandra Shekhar Azad University of Agriculture and Technology, Kanpur to study the "growth and yield of hybrid maize (Zea mays L) under different plant geometry and fertility levels". The investigation result on the pooled basis showed that the maximum plant population, plant height and number of leaves was recorded with the plant geometry $67 \times 20 \mathrm{~cm}(75000$ plants / ha), while maximum fresh and dry weight were recorded in plant geometry $67 \mathrm{~cm} \times 25 \mathrm{~cm}(60000$ plants/ha). In the case of fertility level RDF 100\% and RDF 75\% + Azosp + GM were recorded maximum plant population at initial and plant height at 15 DAS. The maximum plant population at harvest were recorded under the treatment RDF 75\% + Azosp + GM and RDF $75 \%+$ PSB + GM. Treatment RDF $75 \%+$ PSB + GM was recorded maximum plant height at 30 DAS. The maximum plant height at 45 DAS and harvest were recorded with RDF $75 \%+$ Azosp + GM fertility level. The maximum number of leaves, fresh and dry weight was recorded with RDF $100 \%$. The plant geometry $67 \mathrm{~cm} \times 22.5 \mathrm{~cm}$ (66666) plants/ha) and fertility level RDF $75 \%+$ Azosp + GM recorded maximum grain yield of maize.

\section{Introduction}

Maize (Zea mays L.) is one of the most valuable crops having wider adaptability in wide-ranging agro-climatic conditions. Worldwide, maize is known as queen of cereals for the reason that it has the maximum genetic yield potential among the cereals. In addition to staple food for human being and quality feed for animals, it is provides basic raw material for the industry for production of starch for textile, pharmaceutical, cosmetic industries, high quality corn oil, protein, alcoholic beverages etc. In India, maize is cultivated on 9.86 million hectare area with production and productivity of 26.26 million 
tonnes and $2664 \mathrm{~kg} / \mathrm{ha}$, respectively (Anonymous, 2018).

Plant population plays a key role in crop production by effectively use of underground resources and also harvesting as much as solar radiation and in turn better photosynthates formation. The yield of maize crop is directly influenced by population of plant, the total number of plants present at unit area of land. In fact, the yield of a crop is the end product of final plant population; therefore the plant population should not be so large that it can extract most of the moisture from the field before the crop reaches maturity stage. Also, the population should not be reduced so that the moisture remains unused. The optimum plant spacing that allows for ease of the field operations, such a fertilizer application, weeding and decreases competition between plants for light, water and nutrients and makes a favourable micro-climate that reduce the risk for pests and diseases.

Nitrogen is a key element in plant growth. It is found in all plant cells, in plant proteins and hormones, and in chlorophyll. Atmospheric nitrogen is a source of soil nitrogen. Some biofertilizers such as Azospirillum fix atmospheric nitrogen in soil. Nitrogen is also working the utilizing of potassium, phosphorus, and other elements in plant. Nitrogen is biologically combined with $\mathrm{C}, \mathrm{H}$, $\mathrm{O}$, and $\mathrm{S}$ to create amino acids, which are the building blocks of proteins. Amino acids are used in forming protoplasm, the site for cell division and thus for plant growth and development.

Phosphorus is an essential nutrient, it acts as catalysis in the conversion of numerous key biochemical reactions in plants. In photosynthesis and respiration, Phosphorus plays a major role in energy storage and transfer as ADP and ATP (adenosine di- and triphosphate) and DPN and TPN (di- and triphosphopyridine nucleotide). Phosphorus is part of the RNA and DNA structures, which are the major components of genetic information

Potassium increases vigour and disease resistance of plants, helps form and move starches, sugars and oils in plants, and can improve fruit quality. The young seedling does not need much potassium, but the rate of uptake jumps up to a peak level to tasseling.

Biofertilizers have emerged as an important component of the integrated nutrient supply system and hold a great promise to improve crop yields through environmentally better nutrient supplies. The beneficial effect of Azospirillum may derive both from its nitrogen fixation and stimulating effect on root development. The Phosphorus Solubilizing Bacteria (PSB) culture contains millions of soil phosphate solubilizing micro-organism per gram, which is improve mineral uptake by plants through solubilising phosphorus in soil. Green manure is commonly used to improve soil, organic matter, nutrients or to control weeds. Instead of harvesting or grazing, green manure crops are plough in the soil while they are green or soon after flowering.

\section{Materials and Methods}

A field experiment was established at Students' Instructional Farm of C.S. Azad University of Agriculture and Technology, Kanpur, India $\left(26^{\circ} 29^{\prime} 35^{\prime}\right.$ north latitude, $80^{\circ}$ $18^{\prime} 25$ east longitude and an elevation of 125.9 metres above the mean sea level), in two Kharif seasons (2013-14 and 2014-15). There were 12 treatment combinations comprising three plant geometry $67 \times 25 \mathrm{~cm}(60000$ plant/ha), $67 \times 22.5 \mathrm{~cm}(66666$ plant/ha) $67 \times$ $20 \mathrm{~cm}$ (75000 plant/ha) and four fertility level viz, RDF (100\%), RDF (75\%) + Azospirillum + GM., RDF(75\%) + PSB + GM, RDF (50\%)

+ Azospirillum + PSB + GM. These 
treatments were assigned in split plot design with 4 replications. The soil was sandy loam in texture, low in organic carbon and available nitrogen, medium in available phosphorus and available potassium with slightly alkaline in reaction. The rows were oriented east-west. The rainfall during the crop season was 388.6 $\mathrm{mm}$ in 2013-14 and 243.71 $\mathrm{mm}$ in 2014-15. The 'Pro-Agro 4212' of hybrid maize, was sown on 6 and 8 July in 2013 and 2014, respectively. Maize was sown at a row spacing of $67 \mathrm{~cm}$ and plant-to-plant distance of 25 , 22.5 , and $20 \mathrm{~cm}$, respectively. The plant-toplant distance of maize was maintained by thinning. The crops were fertilized by four fertility level, NPK @ RDF (100\%), RDF $(75 \%)+$ Azospirillum + GM., RDF $(75 \%)+$ PSB + GM, RDF (50\%) +Azospirillum + PSB + GM. Biofertlizer and full doses of $\mathrm{P}_{2} \mathrm{O}_{5}$ and $\mathrm{K}_{2} \mathrm{O}$ along with half dose of nitrogen applied at sowing time to the crops. The remaining half of the nitrogen was top dressed in two equal split doses first at 30 DAS and second at tasseling stage. The green manure crop turned into the soil at the time of first interculture operation. Fertilizer requirement of the crops was met through urea, DAP, and muriate of potash. Crop was irrigated as and when required.

\section{Results and Discussion}

\section{Effect of plant geometry}

The pooled data of plant population presented in Table 1, showed that plant population at initial and harvest stages significantly influenced plant geometry. The maximum number (8.75 and 7.09) of plant per square meter was recorded at initial and harvest with $67 \times 20 \mathrm{~cm}$ geometry. The plant geometry $(67 \times$ $22.5 \mathrm{~cm})$ was recorded minimum $(7.93$ and 5.71) plant per square meter at initial and harvest. This is similar to the finding of Thakur et al., (2000). The plant height was recorded at 15, 30, and 45 DAS and harvest stage significantly increased under the treatment of $67 \times 20 \mathrm{~cm}$ over $67 \times 25 \mathrm{~cm}$ and $67 \times 22.5 \mathrm{~cm}$ (Table 1). The percentage increments of $19.42,9.42,7.70$ and $3.05 \%$ over plant geometry of $67 \times 25 \mathrm{~cm}(60000$ plants/ha) were recorded at 15, 30 and 45 DAS and at harvest.

The plant geometry of $67 \times 25 \mathrm{~cm}$ was recorded minimum plant height $(14.57,43.30$, 82.60 and 170.78) $\mathrm{cm}$ at 15,30, 45 DAS and at harvest stage, respectively. This was possibly because increased competition for space, sun light and available nutrients. This is similar to the findings of Kunjir et al., (2007).

The number of leaves per plant was enhanced significantly under the plant geometry of $(67 \times$ $20 \mathrm{~cm}$ ) over rest treatments at all stages except 45 days after sowing (Table 2). On the pooled basis $67 \times 20 \mathrm{~cm}$ spacing recorded 5.25, 4.35, 5.01 and $9.38 \%$ more number of leaves per plant compare other plant geometry at all stages, respectively.

The minimum number of leaves per plant (3.62) was recorded with $67 \times 22.5 \mathrm{~cm}$ at 15 DAS only and $67 \times 25 \mathrm{~cm}$ i.e. $5.75,9.19$ and 17.00 at 30,45 and harvest stages of maize crop, respectively. This might be due to increased growth rate in search for space, sun light and other environmental resources. This is consistent with the findings of Chaugule (2003).

The differences in respect of pooled data of fresh weight per plant due to varying geometry showed significantly (Table 3 ). The higher fresh weight per plant was observed with $67 \times 25 \mathrm{~cm}$ i.e. $76.62 \mathrm{~g}$ at knee height, $442.4 \mathrm{~g}$ at tasseling, $634.98 \mathrm{~g}$ at silking and $663.51 \mathrm{~g}$ at harvest stage of crop, lower fresh weight per plant of $72.73 \mathrm{~g}$ at knee high, $438.75 \mathrm{~g}$ at tasseling, $630.13 \mathrm{~g}$ at silking and $631.33 \mathrm{~g}$ at harvest registered in $67 \times 20 \mathrm{~cm}$, respectively. These result are in close 
agreement with Thakur et al., (2000) and Chaugule (2003), who reported that competition between maize plants for light, soil fertility and other environmental factors was markedly increased into over rest of plant geometry higher plant geometry than in lower plant geometry.

On the basis of pooled data (Table 4) plant dry matter at knee high (12.20 g) and tasseling stage $(155.59 \mathrm{~g})$ was found significantly higher under the geometry of $67 \times 25 \mathrm{~cm}$.

The lowest dry matter (10.37 and $46.63 \mathrm{~g}$ ) per plant observed with plant geometry $67 \times 20$ $\mathrm{cm}$ at knee high and tasseling stage, respectively.

Dry matter per plant at silking (342.2 g) and at harvest $(484.9 \mathrm{~g})$ stages found maximum with $67 \times 25 \mathrm{~cm}$ plant geometry. Lower plant dry weight (331.28 and $453.82 \mathrm{~g}$ ) was recorded with $67 \times 20 \mathrm{~cm}$ at silking and harvest stage respectively. Similar results were discussed by Thavaprakash et al., (2005).

The grain yield of maize differed significantly due to various treatments under study. It could be seen from the Table 4 . The grain yield was significantly increased in $67 \times 22.5 \mathrm{~cm}$ plant geometry which was more than $67 \times 25 \mathrm{~cm}$ and $67 \times 20 \mathrm{~cm}$ plant geometry.

The percentage increments of $67 \times 22.5 \mathrm{~cm}$ and $67 \times 25 \mathrm{~cm}$ plant geometry over $67 \times$ $20 \mathrm{~cm}$ plant geometry were 8.39 and 13.68 , respectively.

This was due to better availability of resources such as sunshine, movement of air and availability of nutrients to the crop under the optimum plant population $67 \times 22.5 \mathrm{~cm}$. Similar finding were reported by Sahoo and Mahapatra (2004).

\section{Effect of fertility level}

The effect of fertility level on plant population was found non-significant. The maximum number of plant per square meter (8.58) was recorded under the treatment RDF $100 \%$ and RDF $(75 \%)+$ Azosp + GM at initial stage but at harvest stage the maximum number of plant per square meter (6.50) was recorded under the treatment RDF $(75 \%)+$ Azosp + GM and RDF $75 \%$ + PSB + GM.

The effect of fertility levels on plant height was not found significant at all stages except 15 days after sowing (Table 1). The maximum plant height $(16.14 \mathrm{~cm}$ and $45.71 \mathrm{~cm})$ was recorded with RDF (100\%) and RDF $(75 \%)+$ $\mathrm{PSB}+\mathrm{GM}$, at 15 and $30 \mathrm{DAS}$ respectively but at 45 DAS and harvest stage $\operatorname{RDF}(75 \%)+$ Azosp + GM was recorded maximum plant height $86.96 \mathrm{~cm}$ and $173.84 \mathrm{~cm}$, respectively.

Fertility level had significant effect on number of leaves per plant (Table 2). The higher numbers of leaves were found under the treatment of RDF $100 \%$ over remaining doses of fertility at 15, 30 and 45 DAS except at harvest stage. The minimum number of leaves were found with RDF (50\%) + Azosp.+ PSB + GM (3.62, 5.66, 8.64 and 16.45 at 15, 30, 45 DAS and at harvest stages, respectively).

The fresh weight per plant on fertility level did not reach level of significant at all stages except at harvest stage (Table 3 ).

The higher fresh weight per plant, $75.42 \mathrm{~g}$ at knee high, 441.32g at tasselling, 633.99g at silking and $663.51 \mathrm{~g}$ at harvest stage was recorded in RDF (100\%) and lowest value for fresh weight $74.42 \mathrm{~g}$ at knee high and 440.18 $\mathrm{g}$ at tasseling, $632.83 \mathrm{~g}$ at silking and $692.42 \mathrm{~g}$ at harvest stages recorded with $\operatorname{RDF}(50 \%)+$ Azosp + PSB + GM. 
Table.1 Effect of plant geometry and fertility level on plant population and plant height of maize crop (pooled data of two years)

\begin{tabular}{|c|c|c|c|c|c|c|}
\hline \multirow[t]{2}{*}{ Treatments } & \multicolumn{2}{|c|}{$\begin{array}{c}\text { plant } \\
\text { population } \\
\left.\text { (Plants / } \mathbf{m}^{2}\right)\end{array}$} & \multicolumn{4}{|c|}{ Plant height (cm) } \\
\hline & $\begin{array}{c}\text { At } \\
\text { Initial }\end{array}$ & $\begin{array}{c}\text { At } \\
\text { harvest }\end{array}$ & $\begin{array}{c}15 \\
\text { DAS }\end{array}$ & $\begin{array}{c}\text { 30 } \\
\text { DAS }\end{array}$ & $\begin{array}{c}45 \\
\text { DAS }\end{array}$ & $\begin{array}{c}\text { At } \\
\text { harvest }\end{array}$ \\
\hline \multicolumn{7}{|c|}{ Plant geometry } \\
\hline $\begin{array}{l}67 \mathrm{~cm} \times 25 \mathrm{~cm}(60000 \\
\text { plants/ha) }\end{array}$ & 7.93 & 5.71 & 14.57 & 43.30 & 82.60 & 170.78 \\
\hline $\begin{array}{l}67 \mathrm{~cm} \times 22.5 \mathrm{~cm} \\
(66666) \text { plants } / \mathrm{ha})\end{array}$ & 8.62 & 6.31 & 16.06 & 44.87 & 87.00 & 173.52 \\
\hline $\begin{array}{l}67 \mathrm{~cm} \times 20 \mathrm{~cm}(75000 \\
\text { plants/ha) }\end{array}$ & 8.75 & 7.09 & 17.40 & 47.38 & 88.96 & 175.99 \\
\hline SEm \pm & 0.180 & 0.160 & 0.04 & 0.52 & 1.31 & 0.36 \\
\hline $\operatorname{LSD}(P=0-05)$ & 0.400 & 0.350 & 0.08 & 1.13 & 0.92 & 0.79 \\
\hline \multicolumn{7}{|l|}{ Fertility level } \\
\hline RDF $100 \%$ & 8.58 & 6.29 & 16.14 & 45.24 & 86.02 & 173.07 \\
\hline RDF 75\% + Azosp + GM & 8.58 & 6.50 & 16.04 & 44.91 & 86.96 & 173.84 \\
\hline RDF $75 \%+$ PSB + GM & 8.45 & 6.50 & 15.96 & 45.71 & 86.87 & 173.54 \\
\hline $\begin{array}{l}\text { RDF 50\% + Azos + PSB + } \\
\text { GM }\end{array}$ & 8.10 & 6.20 & 15.91 & 44.87 & 84.89 & 173.27 \\
\hline SEm \pm & 0.360 & 0.190 & 0.08 & 0.58 & 2.00 & 0.77 \\
\hline $\operatorname{LSD}(P=0-05)$ & N.S. & N.S. & 0.16 & N. S. & N.S & N.S \\
\hline
\end{tabular}

Table.2 Effect of plant geometry and fertility level on number of leaves/plant at 15, 30, 45 DAS and at harvest stages of maize (pooled data of two years)

\begin{tabular}{|c|c|c|c|c|}
\hline \multirow[t]{2}{*}{ Treatments } & \multicolumn{4}{|c|}{ Number of leaves per plant } \\
\hline & 15 DAS & 30 DAS & 45 DAS & At harvest \\
\hline \multicolumn{5}{|c|}{ Plant geometry } \\
\hline $67 \mathrm{~cm} \times 25 \mathrm{~cm}(60000$ plants $/ \mathrm{ha})$ & 3.68 & 5.75 & 9.19 & 16.46 \\
\hline $67 \mathrm{~cm} \times 22.5 \mathrm{~cm}(66666)$ plants/ha) & 3.62 & 5.78 & 9.46 & 16.68 \\
\hline $67 \mathrm{~cm} \times 20 \mathrm{~cm}(75000$ plants $/ \mathrm{ha})$ & 3.81 & 6.00 & 9.65 & 17.00 \\
\hline SEm \pm & 0.03 & 0.02 & 0.32 & 0.12 \\
\hline LSD (P = 0-05) & 0.06 & 0.05 & N.S. & 0.26 \\
\hline \multicolumn{5}{|c|}{ Fertility level } \\
\hline RDF $100 \%$ & 3.87 & 6.16 & 9.96 & 17.00 \\
\hline RDF75\% + Azosp. + GM & 3.62 & 5.79 & 9.72 & 16.83 \\
\hline RDF 75\% + PSB + GM & 3.70 & 5.75 & 9.41 & 16.58 \\
\hline RDF50\% + Azosp. + PSB+GM & 3.62 & 5.66 & 8.64 & 16.45 \\
\hline SEm \pm & 0.04 & 0.05 & 0.32 & 0.20 \\
\hline $\operatorname{LSD}(\mathbf{P}=0-05)$ & 0.09 & 0.10 & 0.65 & N.S. \\
\hline
\end{tabular}


Table.3 Effect of plant geometry and fertility level on fresh weight per plant at knee high, tasseling, silking and harvest stages of maize (pooled data of two years)

\begin{tabular}{|c|c|c|c|c|}
\hline \multirow[t]{2}{*}{ Treatments } & \multicolumn{4}{|c|}{ Fresh weight per plant (g) } \\
\hline & Knee high & Tasseling & Silking & $\begin{array}{c}\text { At } \\
\text { harvest }\end{array}$ \\
\hline \multicolumn{5}{|l|}{ Plant geometry } \\
\hline $67 \mathrm{~cm} \times 25 \mathrm{~cm}(60000$ plants $/ \mathrm{ha})$ & 76.62 & 442.43 & 634.98 & 663.51 \\
\hline $67 \mathrm{~cm} \times 22.5 \mathrm{~cm}(66666)$ plants/ha) & 75.27 & 440.99 & 633.14 & 636.18 \\
\hline $67 \mathrm{~cm} \times 20 \mathrm{~cm}(75000$ plants $/ \mathrm{ha})$ & 72.73 & 438.75 & 630.13 & 631.33 \\
\hline SEm \pm & 0.29 & 0.86 & 0.30 & 0.43 \\
\hline LSD $(P=0-05)$ & 0.64 & 1.88 & 0.66 & 0.94 \\
\hline \multicolumn{5}{|l|}{ Fertility level } \\
\hline RDF $100 \%$ & 75.42 & 441.32 & 633.99 & 644.50 \\
\hline RDF $75 \%+$ Azosp + GM & 75.10 & 441.17 & 632.84 & 643.66 \\
\hline RDF $75 \%$ + PSB + GM & 74.54 & 440.21 & 632.94 & 642.52 \\
\hline RDF50\% + Azosp. + PSB +GM & 74.42 & 440.18 & 632.83 & 642.42 \\
\hline SEm \pm & 0.68 & 0.38 & 0.36 & 0.60 \\
\hline $\operatorname{LSD}(P=0-05)$ & N.S. & N.S. & N.S. & 1.20 \\
\hline
\end{tabular}

Table.4 Effect of plant geometry and fertility level on plant dry weight at knee high, tasseling, silking and at harvest stages and grain yield of maize (pooled data of two years)

\begin{tabular}{|c|c|c|c|c|c|}
\hline \multirow[t]{2}{*}{ Treatments } & \multicolumn{4}{|c|}{ Plant dry weight per plant (g) } & \multirow{2}{*}{$\begin{array}{l}\text { Grain } \\
\text { yield }\end{array}$} \\
\hline & $\begin{array}{l}\text { knee } \\
\text { high }\end{array}$ & Tasseling & Silking & $\begin{array}{c}\text { At } \\
\text { harvest }\end{array}$ & \\
\hline \multicolumn{6}{|l|}{ Plant geometry } \\
\hline $67 \mathrm{~cm} \times 25 \mathrm{~cm}(60000$ plants $/ \mathrm{ha})$ & 12.20 & 155.59 & 342.22 & 484.98 & 53.97 \\
\hline $67 \mathrm{~cm} \times 22.5 \mathrm{~cm}(66666) \mathrm{plants} / \mathrm{ha})$ & 11.38 & 152.31 & 334.77 & 456.82 & 58.50 \\
\hline $67 \mathrm{~cm} \times 20 \mathrm{~cm}(75000$ plants $/ \mathrm{ha})$ & 10.37 & 146.63 & 331.28 & 453.82 & 51.46 \\
\hline $\mathrm{SEm} \pm$ & 0.20 & 0.48 & 0.42 & 0.42 & 0.16 \\
\hline $\operatorname{LSD}(\mathbf{P}=0-05)$ & 0.45 & 1.05 & 0.92 & 0.91 & 0.36 \\
\hline \multicolumn{6}{|l|}{ Fertility level } \\
\hline RDF $100 \%$ & 11.77 & 152.74 & 340.54 & 465.86 & 54.90 \\
\hline RDF $75 \%$ + Azosp + GM & 11.46 & 151.87 & 335.90 & 465.44 & 56.06 \\
\hline RDF $75 \%$ + PSB + GM & 11.03 & 151.16 & 334.10 & 464.91 & 54.36 \\
\hline RDF $50 \%$ + Azosp + PSB + GM & 11.00 & 150.28 & 333.82 & 464.63 & 53.24 \\
\hline SEm \pm & 0.17 & 0.55 & 0.73 & 0.38 & 0.25 \\
\hline $\operatorname{LSD}(P=0-05)$ & 0.35 & 1.11 & 1.46 & 0.77 & 0.50 \\
\hline
\end{tabular}


Significantly higher plant dry matter at knee high $(11.77 \mathrm{~g})$ and tasseling $(152.74 \mathrm{~g})$ was recorded with the application of RDF (100\%), the minimum value of dry matter per plant registered in RDF (50\%) +Azosp + PSB + GM $(11.00 \mathrm{~g}$ at knee high and $150.28 \mathrm{~g}$ at tasseling, respectively). The treatment RDF $100 \%$ was recorded highest dry matter per plant at silking (340.54 g) and harvest stage (465.8g) (Table 4).

In case of fertility level, significantly higher grain yield $(56.06 \mathrm{q} / \mathrm{ha})$ of maize was obtained with the application of RDF $(75 \%)+$ Azosp + GM than rest of doses of fertilizers, whereas lowest grain yield $(53.24 \mathrm{q} / \mathrm{ha})$ was recorded with RDF (50\%) + Azosp + PSB + GM in fertility level.

The percentage increments of $\mathrm{RDF}(75 \%)+$ Azosp + GM over RDF (100\%), RDF(75\%) + PSB + GM and RDF (50\%) + Azosp + PSB + GM were 2.11, 3.13 and 5.30, respectively (Table 4).

The availability of higher nutrition to the growing plant might have resulted in better growth of plant in terms of higher plant population, plant height, on number of leaves per plant fresh and dry weight. Similar result were reported by Kumar et al., (2003)

The better performance of grain yield might be due to arrangement of NPK, biofertilizers and green mannuring to provide suitable quantity of nutrients to the plant resulting in better growth which in turn lead to better physiological process to sink. These results are in conforming to the findings of Rout et al., (2001).

The present study clearly demonstrates that hybrid maize grown with $67 \times 22.5 \mathrm{~cm}$ plant geometry and application of RDF (75\%) + Azospirillum $+\mathrm{GM}$ produce maximum production.

\section{Abbreviations}

RDF- Recommended dose of fertilizer, PSBPhosphate solubilizing bacteria, GM- Green manuring

\section{References}

Anonymous (2018). Agriculture Research Data Book, ICAR, 2018.

Chougule, S.D., (2003). Effect of different plant geometry on sweet corn growth. Maharashtra J. Agric. Sci., 34(12): 122-125.

Kumar, A., Singh, S.N. and Gajendra, G. (2003). Influence of planting pattern and nitrogen and phosphorus fertilization on maize (Zea mays L.) and groundnut (Arachis hypogaea) in intercropping. Indian Journal Agronomy, 48(2): 89-92.

Kunjir, S.S., Chavan, S.A., Bhagat, S.B. and Zende, N.B. (2007). Effect of planting geometry, nitrogen levels and micronutrients on the growth and yield of sweet corn. CropProt. Prod., 2(3): 25-27.

Rout, D., Satapathy, M. R. and Mohapatra, B. K. (2001).Effect of biofertilisers on nitrogen economy in maize Madras Agricultural Journal, 88(7/9), 530532.

Sahoo, S. C. and Mahapatra, P.K. (2004). Response of sweet corn (Zea mays) to nitrogen levels and plant population. Indian Journal of Agricultural Sciences, 74(6): 337-338.

Thakur, D.R., Sharma V. and Sharma, V. (2000).Effect of planting geometry on baby corn yield in hybrid and composite cultivars of maize. Journal Agriculture Science 70(4): 246-247.

Thavaprakaash, N., Velayudham, K., and Muthukumar, V.B. (2005). Effect of crop geometry, intercropping systems and integrated nutrient management 
practices on productivity of baby corn (Zea mays L.) based intercropping systems. Research Journal of
Agricultural and Biological Sciences 1(4): 295-302.

\section{How to cite this article:}

Rajesh Babu, Rampyare and Puspendra Kumar. 2019. Growth and Grain Yield of Hybrid Maize (Zea mays L) under Different Plant Geometry and Fertility Levels. Int.J.Curr.Microbiol.App.Sci. 8(11): 450-457. doi: https://doi.org/10.20546/ijcmas.2019.811.056 